\title{
The influence of stand density on the structure of harvestmen communities (Opiliones) in a submountain beech forest
}

\author{
Slavomír Stašiov*, Marek Svitok \\ Department of Biology and General Ecology, Faculty of Ecology and Environmental Sciences, Technical University \\ in Zvolen, T. G. Masaryka 24, SK-960 53 Zvolen, Slovak Republic
}

\begin{abstract}
StaŠIOV, S., SVITOK, M., 2019. The influence of stand density on the structure of harvestmen communities (Opiliones) in a submountain beech forest. Folia Oecologica, 46: 10-15.

Modification of forest stand density by thinning is a common silvicultural practice implemented in management of production forests. However, changes in the stand density can entail considerable changes to the present forest environment and communities. The current knowledge about the effect of stand density modification on the local animal communities is based mainly on the flagship groups such as carabid beetles or birds. We focused our study on harvestmen. We explored how the stand density influences species composition of this species communities in submountain beech forests. The study was conducted in the Kováčovská dolina valley (Kremnické vrchy Mts, Central Slovakia) in 1997 and 1998, the method used was pitfall trapping. In total, 9 harvestmen species from 5 families were recorded. Prior to our research, the forest stands at the study locality were subject to thinning interventions the intensity of which influenced the structure of the local harvestmen communities. The most pronounced was the effect of very intensive thinning with stand density reduced below 0.5. From the recorded species, four preferred forest stands with lower stand density (Lophopilio palpinalis, Oligolophus tridens, Nemastoma lugubre, Trogulus nepaeformis), two species (Platybunus bucephalus, Dicranolasma scabrum) preferred forest stands with higher stand density. Generalization of the observed pattern requires to explore a wider spectrum of beech forests.
\end{abstract}

\section{Keywords}

canopy cover, community density, cutting, openness, silvicultural practice

\section{Introduction}

To establish the regeneration and subsequent development of forest stands up to harvesting, several silvicultural interventions (called tending interventions) are carried out. These interventions are applied in forest stands at different growth stages, with the aim to provide a healthy environment for their development. One of these operations is thinning. Thinning is defined as a felling made in immature stands with the purpose to improve their growth and to shape the remaining trees, without making permanent breaks in the stand canopy. Thinning is a tending operation carried out in stands first before reacting their sapling stage, and then proceeding up to the beginning of their regeneration period. The thinning principles have been defined in such a way that these are applicable only to pure even-aged or relatively even-aged stands or evenaged groups of trees in a stand. The thinning principles have been developed on the basis of natural development of the stand.

\footnotetext{
*Corresponding author:
} 
The consequence of a thinning is a reduction of stand density, which causes rapid changes to habitat conditions, such as reduced canopy cover, changes in microclimate, and similar (CANHAM et al., 1990; vON GADOw et al., 2002; LeMENIH et al., 2004; ZEIDE, 2004). Several groups of organisms have been recognised as responding sensitively to changes in their habitat conditions through changes in the structure of their communities (BARNA et al., 2010; Cistrone et al., 2015; Schieber et al., 2015).

Harvestmen are terrestrial arachnids. They live mainly on the soil surface, but occasionally they also can occur in deeper layers of soil, in leaf litter, on vegetation or on the walls and inside the buildings. Harvestmen serve several functions in ecosystems. They are known as polyphagous invertebrates preferring animal food. They also prey on various invertebrates. The other food sources for harvestmen are dead invertebrates and other organic remains. This way, harvestmen participate in the maintenance of the natural equilibrium in a wide range of terrestrial habitats. Harvestmen thus contribute to the nutrition cycles and energy flow in nature.

The community structure and diversity in harvestmen is influenced by diverse environmental factors; however, temperature and humidity are considered as the most important (TODD, 1949; BRANQUART et al., 1995; GAVA, 2004; Almeida-Neto et al., 2006). These factors are decisively determined, either directly or indirectly by the type, structure and composition of vegetation (MERINO-SÁINZ and ANADÓn, 2015; Proud et al., 2011; StaŠIOv et al., 2017). There are lacking studies dealing with the impact of stand density on the structure of harvestmen communities.

Our main objective was to assess the effect of the stand density on the structure of harvestmen communities in a submountain beech forest. Exploration of this relationship may help to facilitate the decision on the appropriate intensity of the cutting interventions in silvicultural management in production forests, which would preserve the original biodiversity of invertebrate communities in submountain beech forests.

\section{Material and methods}

The research was carried out at 4 experimental sites (marked as S1 to S4) situated in the Kováčovská dolina valley, the Kremnické vrchy Mts, Central Slovakia $\left(48^{\circ} 38^{\prime} \mathrm{N}, 19^{\circ} 4^{\prime} \mathrm{E}\right)$, with altitude ranging $450-475 \mathrm{~m}$ a.s.1. All experimental plots were located on the same slope with a $30 \%$ inclination and western exposure. The local soil is a loamy-clay cambisol with a depth of 51-70 cm.

The forest stand consists of Fagus silvatica (62\% of dominance), Abies alba (22\%), Quercus dalechampii (7\%), Carpinus betulus (6\%) and Tilia cordata (3\%), aged 90 years on average.

The stand density on the experimental plots was modified in February 1984 in the following way: experimental site $\mathrm{S} 1-0.3$ - heavy thinning (i.e. $30 \%$ stand density), $\mathrm{S} 2-0.5$ - moderate thinning, S3 - 0.7 - light thinning. The experimental site $\mathrm{S} 4$ remained without changes. The stand densities on these sites in 1996 represented the values: $0.45,0.57,0.82,1.00$ for the sites S1, S2, S3 and S4, respectively (JEŽík, 1996). The crown cover (proportion of a stand covered by the crowns of live trees) of the tree layers 1996 was: S1 - 103.8\%, S2 - 133.7\%, S3 - 179.0\%, S4 - 210.9\% (JEŽÍK, 1996). Modification of the stand density has also changed the stand canopy openness in the growing season (S1 - 27-46\%, S2 - 10-18\%, S3 - 4-8\%, S4 - 3-5\%; STŘELEC, 1993).

Our research was carried out in 1997 and 1998, by pitfall trapping. On each experimental site, the invertebrates were trapped into 5 pitfall traps, placed on a contour line, spaced 5 $\mathrm{m}$ apart. The traps were cylindrical jars (each of volume 0.7 liters, upper diameter of $7.5 \mathrm{~cm}$ and depth of $14 \mathrm{~cm}$ ) filled with $1 \%$ formaldehyde to one-third of their volume.

In the two observation years, the traps were exposed from April 4 to October 31. The trapped invertebrates were collected at 30-day intervals. The obtained samples were stored in $70 \%$ ethyl alcohol, separated, determined using a dissecting microscope, and deposited in the collection of the first author.

The Shannon index of species diversity $(H)$ working with the natural logarithm was used to compare the diversity of harvestmen communities on the particular experimental plots (SHANNON, 1948). The evenness of communities $(E)$ was calculated using the Shannon-Weaver index (BEGON et al., 1990)

Similarity in the harvestmen community composition between the different experimental plots (S1-S4) was assessed with using Bray-Curtis distances. Prior to the calculation of distances, the species abundances were squareroot transformed to substitute the data on a similar scale. This approach guaranteed that the abundant species did not dominate the results. The generalized discriminant analysis (GDA, ANDERSON and RoBINSON, 2003) was used to display the distance matrix in the ordination space. GDA is a form of canonical analysis on the principal coordinates (ANDERSON and WiLLIS, 2003) maximising the separation among a priori defined groups, such as the stands with different densities in our case. The number of the principle coordinates retained in GDA was determined using the mis-classification error. Since the species identity is lost in GDA, we added species scores to the constrained ordination as the weighted averages of the sample scores.

The analyses were performed in R ( $\mathrm{R}$ CORE TEAM, 2018) using packages BiodiversityR (KINDT and CoE, 2005) and vegan (OKSANEN et al., 2018).

\section{Results}

In total, 942 harvestmen individuals were obtained from the study area. These were assorted into 9 species from 5 families, which represents $25.7 \%$ of the harvestmen fauna in Slovakia recognized to date. The data on the total epigeic activity of the species and diversity characteristics of harvestmen communities (number of species, Shannon index, evenness) recorded at the experimental sites in 1997-1998 are summarised in Table 1. 
Table 1. Chosen parameters of harvestmen communities recorded at the experimental sites S1, S2, S3, S4

\begin{tabular}{|c|c|c|c|c|c|}
\hline Family/Species & $\mathrm{S} 1$ & $\mathrm{~S} 2$ & S3 & S4 & $\sum$ \\
\hline \multicolumn{6}{|l|}{ Phalangiidae } \\
\hline Lophopilio palpinalis (Herbst, 1799) & 98 & 33 & 6 & 7 & 144 \\
\hline Mitopus morio (Fabricius, 1799) & 1 & & & & 1 \\
\hline Oligolophus tridens (C. L. Koch, 1836) & 114 & 24 & 11 & 5 & 154 \\
\hline Platybunus bucephalus (C. L. Koch, 1835) & 10 & 4 & 37 & 43 & 94 \\
\hline \multicolumn{6}{|l|}{ Sclerosomatidae } \\
\hline Leiobunum gracile Thorell, 1876 & & & & 3 & 3 \\
\hline \multicolumn{6}{|l|}{ Dicranolasmatidae } \\
\hline Dicranolasma scabrum (Herbst, 1799) & 7 & 11 & 89 & 44 & 151 \\
\hline \multicolumn{6}{|l|}{ Nemastomatidae } \\
\hline Mitostoma chrysomelas (Hermann, 1804) & & & 4 & 1 & 5 \\
\hline Nemastoma lugubre (Müller, 1776) & 71 & 36 & 3 & 9 & 119 \\
\hline \multicolumn{6}{|l|}{ Trogulidae } \\
\hline Trogulus nepaeformis (Scopoli, 1763) & 112 & 42 & 65 & 49 & 268 \\
\hline$\sum$ ex. & 413 & 150 & 215 & 164 & 942 \\
\hline$\sum$ spp. & 7 & 6 & 7 & 8 & 9 \\
\hline$H$ & 1.53 & 1.61 & 1.42 & 1.59 & \\
\hline$E$ & 0.79 & 0.90 & 0.73 & 0.76 & \\
\hline
\end{tabular}

$\sum$ ex., total number of individuals; $\sum$ spp., number of species; $H$, Shannon index; $E$, evenness.

The site with the highest stand density (S4) hosted two species (Leiobunum gracile, Mitostoma chrysomelas) not recorded on the sites with lower stand density (S1, S2). On the contrary, Mitopus morio was recorded only on the site with the lowest stand density (S1); however, only as a single specimen.

We also recorded considerable differences among the species in their activity patterns. An apparent negative correlation between epigeic activity and stand density was found in four species (Lophopilio palpinalis, Oligolophus tridens, Nemastoma lugubre, Trogulus nepaeformis). In two other species (Platybunus bucephalus, Dicranolasma scabrum), their epigeic activity increased with increasing stand density (Table 1).

The results did not demonstrate considerable influence of stand density on the Shannon index of species diversity or the evenness of harvestmen communities. Nevertheless, in the case of evenness, higher values were found on the site with lower stand density.

Generalised discriminant analysis working with nine principal coordinates maximized the proportion of samples correctly classified to the particular forest stands $(61 \%$ classification accuracy). An ordination site of GDA shows a clear separation of the harvestmen communities along the first canonical axis (Fig. 1). For the heavily thinned stand $\mathrm{S} 1$ there was typical a higher abundance of $L$. palpinalis, $O$. tridens and $N$. lugubre and the seasonal samples can be reliably assigned to this stand (79\% classification accuracy). Similarly, the samples from lightly thinned stand S3 showed a high classification accuracy (79\%) and there displayed characteristic higher abundances of D. scabrum and M. chrysomelas. The samples from the remaining stands S2 and S4 were more variable in the species composition and, as such, they formed transitions between $\mathrm{S} 1$ and S3. The high within-group variance led to low classification accuracy in these stands ( $\mathrm{S} 2-36 \%$ and $\mathrm{S} 4-50 \%$ ).

\section{Discussion}

The ascertained species structure in the studied harvestman communities corresponds to the environmental conditions in the submountain beech forests. The relatively high species diversity reflects a relatively low disturbance of the studied area.

The high species richness of harvestmen communities in beech forests was also confirmed by other authors. For example, MiHÁL and ČERnECKÁ (2017) and also ČERNECKÁ et al. (2017) evaluated harvestmen communities in sub-mountain beech stands in the Western Carpathians. They found in total 16 species representing $45.7 \%$ of the Slovak opiliofauna. MERINO-SÁINZ and ANADóN (2015) found 11 harvestmen species in natural beech forest in the Muniellos Biosphere Reserve (Asturias, Spain). 


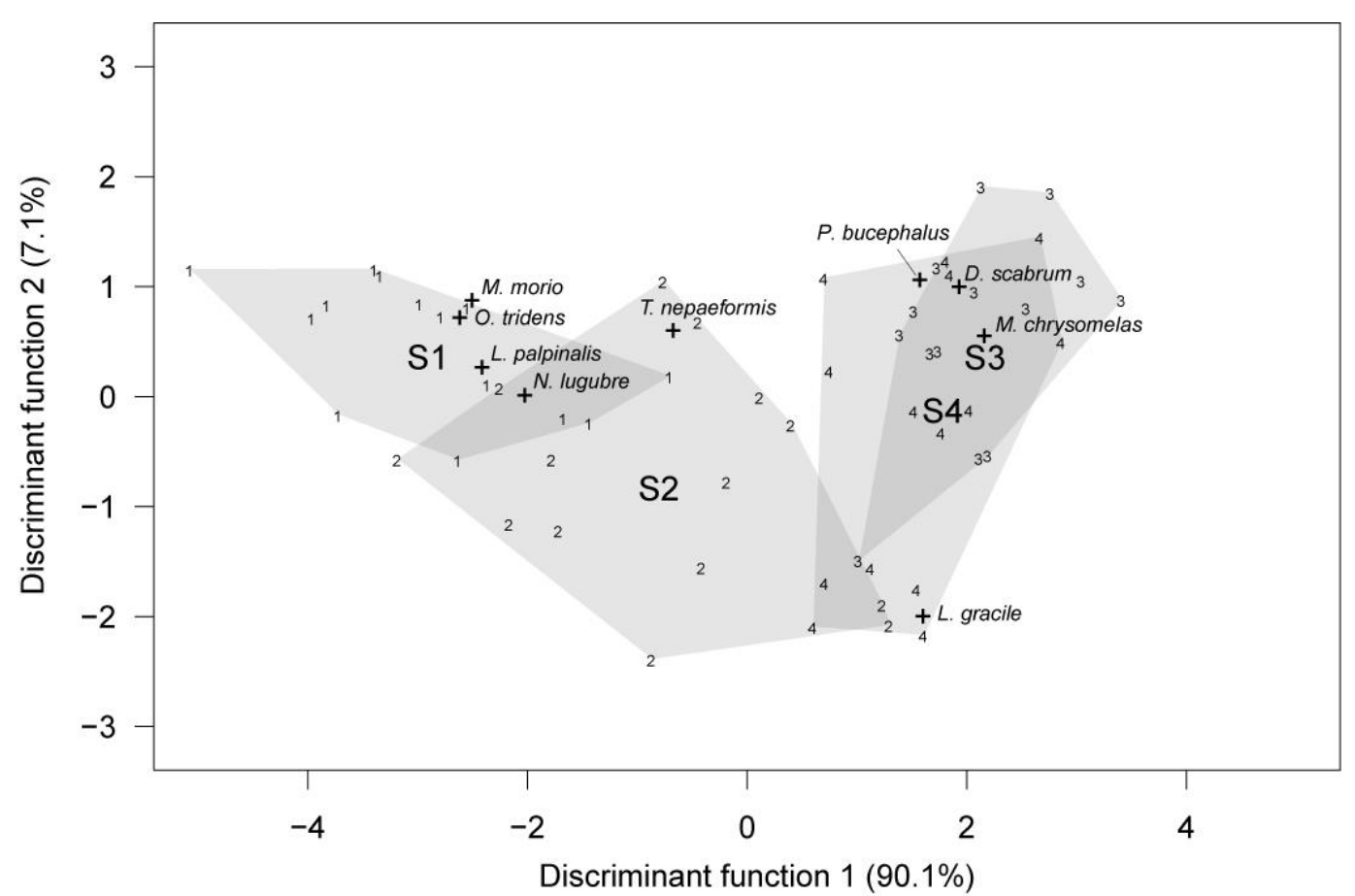

Fig. 1. GDA ordination site showing differences in composition of harvestmen communities of four forest stands (S1S4). Scores of seasonal samples are assigned by small numbers referring to stand numbers (1-4). Species scores $(+)$ are superimposed as weighted averages. Axis labels indicate the proportion of between-group variance (\%) explained by the first two linear discriminant functions.

The high species richness of harvestmen communities in beech forests is implied by the fact that the beech forests offer very favourable habitats for several species. Almost half of all harvestmen species in Slovakia (17 species from the total number of 35 Slovak harvestman species) can be found in the beech forests (monocultures or mixed forests) (Stašıov, 2004a).

Concerning the ecological requirements, the vast majority of the recorded species belong to those favouring the hygrophilous deciduous and mixed forests (Dicranolasma scabrum, Leiobunum gracile, Lophopilio palpinalis, Platybunus bucephalus, Trogulus nepaeformis). Four species are categorised as euryvalent (Mitopus morio, Mitostoma chrysomelas, Nemastoma lugubre, Oligolophus tridens) (STAŠIOv, 2004a).

In terms of the geographical distribution, the found species of harvestmen can be classed into four groups: most of them are European species with a relatively frequent occurrence in Slovakia (Lophopilio palpinalis, Mitostoma chrysomelas, Nemastoma lugubre, Oligolophus tridens, Trogulus nepaeformis), two species (Dicranolasma scabrum, Platybunus bucephalus) belong to South-Eastern European, the species Mitopus morio is Holarctic and Leiobunum gracile is known as Central European (STAŠIOV, 2004a). The recorded species mostly belong to the native European fauna. They are wide-spread in various forest habitats from lowlands to mountains.

Considering the three most numerous species recorded (T. nepaeformis, O. tridens, D. scabrum), MiнáL and
ČERNECKÁ (2017) confirmed only T. nepaeformis as a dominant component of harvestmen communities in submountain beech stands of the Western Carpathians. These authors recorded T. nepaeformis with a $19.9 \%$ dominance - as the second most abundant harvestman following Lophopilio palpinalis with $22.8 \%$ dominance. In a beech forest in the Malý Polom National Nature Reserve (NNR), the Kysuce Protected Landscape Area, Slovakia, StašIOV et al. (1997) found Platybunus bucephalus as the most abundant harvestman with $31.8 \%$ dominance, followed by $O$. tridens with $26.2 \%$ dominance. In beech forests in the Stužica NNR, Bukovské vrchy Mts., Slovakia, STAŠIOV (2004b) recorded 9 harvestmen species from which Mitopus morio was the most numerous (56.9\% dominance). On the contrary, in the present study this species was found the rarest one. The second most numerous harvestman in the Stužica NNR was $P$. bucephalus with $13.7 \%$ dominance. This variation among all the examined beech forests could result from different altitudes with different climatic conditions. The altitudinal range of our experimental sites was $450-475 \mathrm{~m}$ a.s.l. while the altitude of the other above mentioned sites was $900 \mathrm{~m}$ a.s.l (Malý Polom NNR) and 640-1,210 m a.s.1. (Stužica NNR). The species M. morio and $P$. bucephalus prefer higher altitudes (above $600 \mathrm{~m}$ a.s.1.) compared to T. nepaeformis, O. tridens and D. scabrum (400-800 $\mathrm{m}$ a.s.1.), recorded as the most numerous in our study (StašIov, 2008).

The observed values of epigeic activity indicate that the four recorded species (L. palpinalis, O. tridens, N. lu- 
gubre, T. nepaeformis) prefer forest stands with a lower stand density and also with a sparse canopy cover. Therefore, it can be assumed that these species have not special demands on high humidity of their environment and that they are more tolerant to drier conditions than the species P. bucephalus and D. scabrum which preferred the sites with higher stand density (Table 1).

Generalised discriminant analysis (Fig. 1) revealed that the structure of harvestmen communities of the sites with lower stand density (S1, S2) displayed more variance between the sites than in the case of sites with higher stand density (S3, S4). Apparently, the effect of stand density on harvestmen community composition increased with the degree of thinning.

Beside the harvestmen, there was also studied the influence of stand density on millipedes (Diplopoda) and centipedes (Chilopoda) communities (STAŠIOV and SVITOK, 2014). Based on the previous results, we concluded that in the submountain beech forests, the density of mature stands, resulting from their previous thinning may significantly influence the structure of the studied communities of epigeic macrofauna (including harvestmen) only if the thinning was very intensive, reducing the stand density below 0.5 .

\section{Summary}

Thinning interventions applied in the submountain beech forests during their growth impact the density of the mature stands which significantly influenced the structure of harvestmen communities in these stands. Particularly evident was the effect of very intensive thinning with the stand density reduction below 0.5 . However, the species varied in their response to the stand density modifications. Four recorded species preferred forest stands with lower stand density (Lophopilio palpinalis, Oligolophus tridens, Nemastoma lugubre, Trogulus nepaeformis) and four species (Platybunus bucephalus, Leiobunum gracile, Dicranolasma scabrum, Mitostoma chrysomelas) preferred forest stands with higher stand density. Therefore, the effect of stand density should be considered not only for the whole community of the studied invertebrate group, but also for the particular species constituting the assemblages at the forest site concerned. The obtained results relate to the conditions of low-altitude beech forests. There remains a question to answer whether this pattern is also valid for beech forest stands situated at higher altitudes.

\section{References}

Almeida-Neto, M., Machado G., Pinto-da-Rocha, R., Giaretta, A.A., 2006. Harvestmen (Arachnida: Opiliones) species distribution along three Neotropical elevational gradients: an alternative rescue effect to explain Rapoport's rule? Journal of Biogeography, 33: 361-375.

Anderson, M.J., Robinson, J., 2003. Generalised discriminant analysis based on distances. Australian and New Zea- land Journal of Statistics, 45: 301-318.

Anderson, M.J., Willis, T.J., 2003. Canonical analysis of principal coordinates: a useful method of constrained ordination for ecology. Ecology, 84: 511-524.

Barna, M., Sedmák, R., Marušák, R., 2010. Response of European beech radial growth to shelterwood cutting. Folia Oecologica, 37 (2): 125-136.

Begon, M., Harper, J.L., Towsend, C.R., 1990. Ecology: individuals, populations and communities. 2nd ed. Boston: Blackwell Scientific Publications. 945 p.

Branquart, É., Kime, R.D., Dufrêne, M., Tavernier, J., WAUHTY, G., 1995. Macroarthropod-habitat relationships in oak forest in South Belgium. 1. Environments and communities. Pedobiologia, 39: 243-263.

Canham, C.D., Denslow, J.S., Platt, W.J., Runkle, J.R., Spies, T.A., White, P.S., 1990. Light regimes beneath closed canopies and tree-fall gaps in temperate and tropical forests. Canadian Journal of Forest Research, 20: 620-631.

Cistrone, L., Altea, T., Matteucci, G., Posillico, M., De Cinti, B., Russo, D., 2015. The effect of thinning on bat activity in Italian high forests: the LIFE+ "ManFor C.BD." experience. Hystrix, the Italian Journal of Mammalogy, 26 (2): 125-131.

ČERnECKÁ, L., MiHÁL, I., JARČUŠKA, B., 2017. Response of ground-dwelling harvestman assemblages (Arachnida: Opiliones) to European beech forest canopy cover. European Journal of Entomology, 114: 334-342.

GAVA, R., 2004. Vertical distribution of Diplopoda populations from deciduous forests. Archives of Biological Sciences, Belgrade, 56: 59-64.

JEŽík, M., 1996. Základné údaje EES Kremnické vrchy v závislosti od monitorovacích plôch, výmery a druhy drevín pred a po t'ažbovom zásahu v r. 1989 [The basic data of the Ecological Experimental Station (EES) in Kremnické vrchy Mts., depending on the monitoring sites, area and tree species before and after the mining intervention in the year 1989]. Research report. Zvolen: Ústav ekológie lesa SAV. 6 p.

Kindt, R., Coe, R., 2005. Tree diversity analysis. A manual and software for common statistical methods for ecological and biodiversity studies. Nairobi: World Agroforestry Centre (ICRAF). $196 \mathrm{p}$.

Lemenih, M., Gidyelew, T., Teketay, D., 2004. Effects of canopy cover and understory environment of tree plantations on richness, density and size of colonizing woody species in southern Ethiopia. Forest Ecology and Management, 194: 1-10.

Merino-SÁINZ, I., ANADÓN, A., 2015. Local distribution patterns of harvestmen (Arachnida: Opiliones) in a Northern Temperate Biosphere Reserve landscape: influence of orientation and soil richness. Belgian Journal of Zoology, 145 (1): 3-16.

MinÁL, I., ČerneckÁ, L., 2017. Structure of harvestmen (Arachnida, Opiliones) communities in different, anthropically disturbed beech ecosystems (Western Carpathians, Slovakia). Vestnik Zoologii, 51 (3): 259-270.

Oksanen, J., Blanchet, F.G., Friendly, M., Kindt, R., LeGendre, P., McGlinn, D., Minchin, P.R., O’Hara, R.B., Simpson, G.L., Solymos, P., Stevens M.H.H., Szoecs, E., Wagner, H., 2018. Vegan: Community ecology package. R package version 2.5-2.

Proud, D.N., Tibbetts, J.A., Moore M.K., Townsend, V.R.JR., 2011. Diversity of neotropical harvestmen 
(Arachnida: Opiliones) inhabiting logs and palm fronds in the rain forests of Trinidad. Annals of the Entomological Society of America, 104 (2): 241-248.

R CORE TEAM, 2018. R: a language and environment for statistical computing. Vienna, Austria: R Foundation for Statistical Computing.

Schieber, B., Kubov, M., PavelKa, M., Janík, R., 2015. Vegetation dynamics of herb layer in managed submountain beech forest. Folia Oecologica, 42: 35-45.

SHANnON, C.E., 1948. A mathematical theory of communication. AT\&T Technical Journal, 27: 379-423, 623-656.

StaŠıov, S., 2004a. Kosce (Opiliones) Slovenska [Harvestmen (Opiliones) of Slovakia]. Vedecké štúdie, 3/2004/A Zvolen: Technická univerzita vo Zvolene. 119 p.

Stašiov, S., 2004b. Notes to the harvestmen (Opiliones) of the Stužica National Reservation (Bukovské vrchy Mts.). In MidRiak, R. (ed.). Biosférické rezervácie na Slovensku $V$. Zborník referátov z 5. národnej konferencie o BR Slovenska konanej v Novej Sedlici 29. - 30. 9. 2004. Zvolen: Technická univerzita vo Zvolene, p. 139-142.

StAšıov, S., 2008. Altitudinal distribution of harvestmen (Euchelicerata: Opiliones) in Slovakia. Polish Journal of Ecology, 56 (1): 157-163.

StaŠIOv, S., BituŠík, P., ŠAmaJ, J., 1997. Kosce (Opiliones) NPR Malý Polom (CHKO Kysuce) [The harvestmen (Opiliones) of the Malý Polom National Nature Reservation (the Kysuce Protected Area Landscape)]. Ochrana prírody, Banská Bystrica, 15: 119-125.

Stašıov, S., Michalková, E., LukÁčıK, I., ČIliak, M., 2017.
Harvestmen (Opiliones) communities in an arboretum: influence of tree species. Biologia, 72 (2): 184-193.

Stašıov, S., SvitoK, M., 2014. The influence of stand density on the structure of centipede (Chilopoda) and millipede (Diplopoda) communities in the submountain beech forest. Folia Oecologica, 41: 195-201.

STŘELEC, J., 1993. Fotosyntetické aktívne žiarenie a teplota v prízemnej vrstve vzduchu a v pôde bukového ekosystému pri rôznom zakmenení a ich bioklimatické účinky [Fotosyntetic active radiation and temperature of air in the ground layer and in the soil of the beech ecosystem at different forest stand density and their bioclimatic effects]. In KodríK, M., Kontrišová, O. (eds). Výskum podhorských bučin (EES Kremnické vrchy). Zvolen: Ústav ekológie lesa SAV. 4 p.

ToDD, V., 1949. The habits and ecology of the British harvestmen (Arachnida, Opiliones), with special reference to those of the Oxford district. Journal of Animal Ecology, 18: 209-229.

Von Gadow, K., Nagel, J., Saborowski, J. (eds), 2002. Continuous cover forestry: assessment, analysis, scenarios (managing forest ecosystems). Dordrecht: Kluwer. 348 pp.

ZeIDE, B., 2004. Optimal stand density: a solution. Canadian Journal of Forest Research, 34 (4): 846-854.

Received November 27, 2018 Accepted March 13, 2019 